\title{
Liquidity Management and Banks Financial Performance in Kuwait
}

http://doi.org/ 10.21272/fmir.4(3).102-108.2020

Musaed Sulaiman AlAli, ORCID: https://orcid.org/0000-0003-0802-5440

Department of Insurance and Banking, College of Business Studies; the Public Authority for Applied Education and Training (PAAET), Kuwait

\begin{abstract}
Bank liquidity plays an important role in determining the bank's financial performance. This study examines the impact of liquidity on the financial performance of ten Kuwaiti banks, whose shares are listed on the Kuwait Stock Exchange in the period 2010-2018. The article is based on the analysis of return on assets (ROA) and return on equity (ROE) as indicators of the bank's financial efficiency in comparison with the five liquidity ratios. The results of the study showed a statistically significant direct relationship between ROA and the ratio of loans to total assets, the ratio of loans and deposits and the ratio of the financing deficit to total assets. According to the results of the calculations, a statistically significant inverse relationship between the ROA of liquid assets and the total assets and the ratio of liquid assets and deposits. The determination of return on equity (ROE) showed their statistically significant feedback only on liquid assets and deposits, while a significant direct relationship with the ratio of loans to total assets, the ratio of loans to deposits and the deficit of funding to the total assets. The results of this study provide an explanation of the contradictory results presented in the literature on the impact of liquidity on the financial results of banks. They found that the direction of the relationship depended on which financial ratio was used to explain the relationship (in this study, two ratios showed feedback, while the other three showed a direct ratio). The lack of a universal liquidity ratio will eventually lead to conflicting results.
\end{abstract}

Key words: liquidity, financial indicators, financial results, Kuwait banks, Kuwait Stock Exchange.

JEL classification: G00, C3, M21.

This work is licensed under a Creative Commons Attribution 4.0 International License

Cite as: AlAli, M. S. (2020). Liquidity Management and Banks Financial Performance in Kuwait. Financial Markets, Institutions and Risks, 4(3), 102-108. http://doi.org/ 10.21272/fmir.4(3).102-108.2020.

(C) The Author, 2020. This article is published with open access at Sumy State University.

\section{Introduction}

Liquidity management is an important tool for the management of organizations; it reflects the organization's ability to repay short-term liabilities. Amengor (2010) defines liquidity in commercial banks as its ability to fund all contractual obligations as they fall due. These obligations may include lending and investment commitments and deposit withdrawals and liability maturates, in the normal course of business. The main objective for any bank is to maximize profitability which is made of interest rate differential between loans and deposits and investments returns and since deposits are payable upon demand, managing healthy liquidity level while at the same time maximizing profit becomes central issues in banking. Profitability is the main concern for shareholders since it determines their return on investment. While liquidity is the main concern for depositors since it indicates the bank ability to accommodate their withdrawal needs which are normally on demand or on a short notice as the case may be (Olagunji et al., 2011). According to trade-off theory, holding a high liquidity may reduce bank risk which in turn reduces the compensation demanded by investors for bankruptcy probability but on the other hand holding high liquidity level would result in lower returns to the bank since these funds are held idle or with very low returns (Osborne et al. 2012). To overcome the problem of unused funds held for liquidity purposes, anticipated income theory suggests that bank's liquidity can be managed through the proper phasing and structuring of the loan commitments made by a bank to the customers. Nzotta (1997) stated that banks should pay more attention to borrowers' worthiness to ensuring adequate liquidity. 
There have been many researches done in examining the relation between liquidity and bank profitability and most of them found that liquidity has a significant effect on bank profitability. But despite agreeing on the statistical effect, the direction of the relation is still debatable. Eichengreen and Gibson (2001) stated that various authors have found varying relationships between liquidity and profitability of banks in various countries.

Imad et al. (2011) studied Jordanian banks for the purpose of investigating the nature of the relationship between financial performance and liquidity level of ten banks over the period 2001 to 2010. Using return on assets (ROA) and the rate of return on equity (ROE), as financial performance proxies, results showed that the Jordanian bank's liquidity explain a significant part of the variation in banks' profitability. Bourke (1989) studied the relation between liquid assets and bank profitability for 90 banks in Europe, North America and Australia over the period 1972-1981 and found a positive relation between them. In studying the relation between credit management, liquidity position and profitability of ten Nigerian banks over the period 20062010, Kehinde (2013) found that liquidity has significant positive effect on return on asset (ROA). Idowu et al (2017), using the data of four Nigerian banks over the period 2007-2016, studied the relation between liquidity, return on assets (ROA), and return on equity (ROE). Using Pearson correlation co-efficient technique, the study showed direct statistically significant relationship between banks' liquidity, return on assets (ROA) and return on equity (ROE). The study suggested that good liquidity management can improve the financial performance of banks. Heibati et al. (2009) examined the financial performance of banks in Iran and Arabic countries of Arabian Gulf area. Empirical results from regression analysis of cross-country panel data of the banks showed statistically direct significant relationship between liquidity and profitability of the banks especially during initial years of their activity.

On the other hand, other researchers argued that, holding liquid assets imposes an opportunity cost on the bank given their low return relative to other assets, thereby having a negative effect on profitability. Eichengreen and Gibson (2001) argued that tying up funds in low return liquid investments would have an effect on bank profitability. Al-Yatama et al. (2020) studied the effect of risk factors on the financial performance of insurance companies listed at Kuwait Stock Exchange (KSE) over the period 2009 to 2017. They found that liquidity risk, measured by current liabilities to current assets, does not have any effect on the financial performance of insurance companies. Molyneux and Thornton (1992) and Goddard et al. (2004) found evidence of negative relationship between the two variables, liquidity and financial performance, for European banks in the late 1980's and mid-1990's respectively.

\section{Methodology}

This study attempts to examine the liquidity effect on the financial performance of commercial banks listed at Kuwait stock exchange (KSE) over the period 2010-2018. A panel data is used to evaluate that relation where the return on assets (ROA) and return on equity (ROE) are set as dependent variables and five liquidity ratios as independent variables, as presented in Table 1. In examining the relation between return on assets (ROA) and the liquidity ratios is presented in formula 1 . While in evaluating the effect of liquidity ratios on return on equity (ROE) is estimated using formula 2 .

$R O A_{t}=\alpha+\beta_{1} L 1_{t}+\beta_{2} L 2_{t}+\beta_{3} L 3_{t}+\beta_{4} L 4_{t}+\beta_{5} L 5_{t}+\varepsilon$
$R O E_{t}=\alpha+\beta_{1} L 1_{t}+\beta_{2} L 2_{t}+\beta_{3} L 3_{t}+\beta_{4} L 4_{t}+\beta_{5} L 5_{t}+\varepsilon$

Where $\varepsilon$ is the error term.

\begin{tabular}{|c|c|c|c|}
\hline Variable & Abbreviation & Ratio Calculation & Expected Relation with Profitability \\
\hline Return on Assets & ROA & $\frac{\text { Net Profit }}{\text { Total Assets }}$ & \\
\hline Return on Equity & ROE & $\frac{\text { Net Prof it }}{\text { Shareholders Equity }}$ & Inverse \\
\hline Liquid Assets to Total Assets & L1 & $\frac{\text { Liquid Assets }}{\text { Total Assets }}$ & Inverse \\
\hline Liquid Assets to Deposits & L2 & $\frac{\text { Liquid Assets }}{\text { Deposits }}$ & Direct \\
\hline Loans to Total Assets & L3 & $\frac{\text { Loans }}{\text { Total Assets }}$ & Direct \\
\hline Loans to Deposits & L4 & $\frac{\text { Loans }}{\text { Deposits }}$ & Toposits \\
\hline Financing Gap to Total Assets & L5 & & \\
\hline
\end{tabular}

Source: compiled by the author. 
Where ROA measures bank's profitability relative to its assets and thus the bank's overall performance financial performance, ROE is set to measure the return bank makes on shareholders' equity. L1 is set to measure the ability of a bank to absorbing liquidity shocks, where a higher ratio would mean a higher ability to absorb shocks. L2 is used to measure bank's liquidity in the case that the bank cannot borrow from other banks. A high ratio means that the bank is able to cope long term liquidity risk. L3 measures the portion of loans to total assets, where it shows the percentage of the bank's assets related to illiquid loans. A higher ratio would indicate less liquidity. L4 indicates the relationship of illiquid assets and liquid liabilities. When this ratio is high, it means that the bank is less liquid. L5 measures liquidity risk exposure, which is defined as the difference between a bank's loans and customer deposits, financing gap, to total assets. A higher ratio would indicate less liquidity for the bank.

\section{Data and Empirical Results}

This study is based on the financial ratios of 10 banks that are listed at Kuwait Stock Exchange (KSE) over the period 2010 to 2018. The data for this research were obtained from the banks financial statements that were downloaded from Kuwait Stock Exchange (KSE) website.

Return on assets (ROA) is a ratio that measures the ability of the bank in generating profits from the assets it has. Comparing the ROA between banks under study is presented in table 2 . From the table it can be seen that NBK was the best performer during the study period by achieving a mean return of $1.59 \%$ followed by AUB. On the flip side, WBK was the worst performer and that can be contributed to its young age since the bank was established in 2010.

Table 2. Banks ROA Comparison

\begin{tabular}{|c|c|c|c|c|c|c|c|c|c|c|}
\hline ROA & 2010 & 2011 & 2012 & 2013 & 2014 & 2015 & 2016 & 2017 & 2018 & Average \\
\hline ABK & $1.80 \%$ & $1.63 \%$ & $1.01 \%$ & $1.11 \%$ & $1.07 \%$ & $0.70 \%$ & $0.76 \%$ & $0.82 \%$ & $0.93 \%$ & $1.09 \%$ \\
\hline BBK & $0.37 \%$ & $1.26 \%$ & $1.05 \%$ & $0.45 \%$ & $0.94 \%$ & $1.29 \%$ & $0.92 \%$ & $0.93 \%$ & $1.14 \%$ & $0.93 \%$ \\
\hline CBK & $1.12 \%$ & $0.02 \%$ & $0.03 \%$ & $0.60 \%$ & $1.17 \%$ & $1.14 \%$ & $1.22 \%$ & $1.26 \%$ & $1.43 \%$ & $0.89 \%$ \\
\hline GBK & $0.41 \%$ & $0.64 \%$ & $0.64 \%$ & $0.63 \%$ & $0.67 \%$ & $0.72 \%$ & $0.79 \%$ & $0.84 \%$ & $0.94 \%$ & $0.70 \%$ \\
\hline NBK & $2.35 \%$ & $2.23 \%$ & $1.88 \%$ & $1.35 \%$ & $1.26 \%$ & $1.26 \%$ & $1.29 \%$ & $1.31 \%$ & $1.39 \%$ & $1.59 \%$ \\
\hline AUB & $0.94 \%$ & $0.97 \%$ & $1.44 \%$ & $1.36 \%$ & $1.29 \%$ & $0.89 \%$ & $1.02 \%$ & $1.29 \%$ & $1.31 \%$ & $1.17 \%$ \\
\hline BYK & $0.46 \%$ & $0.51 \%$ & $0.51 \%$ & $0.58 \%$ & $1.08 \%$ & $1.12 \%$ & $1.19 \%$ & $1.20 \%$ & $1.29 \%$ & $0.88 \%$ \\
\hline KFH & $0.57 \%$ & $0.28 \%$ & $0.84 \%$ & $0.98 \%$ & $0.93 \%$ & $1.02 \%$ & $1.11 \%$ & $1.23 \%$ & $1.48 \%$ & $0.94 \%$ \\
\hline KIB & $1.47 \%$ & $0.97 \%$ & $1.05 \%$ & $0.88 \%$ & $0.83 \%$ & $0.90 \%$ & $0.99 \%$ & $0.93 \%$ & $0.97 \%$ & $1.00 \%$ \\
\hline WBK & $\mathrm{n} / \mathrm{a}$ & $\mathrm{n} / \mathrm{a}$ & $-0.83 \%$ & $-0.91 \%$ & $0.02 \%$ & $0.13 \%$ & $0.23 \%$ & $0.42 \%$ & $0.58 \%$ & $-0.05 \%$ \\
\hline Average & $1.05 \%$ & $0.95 \%$ & $0.76 \%$ & $0.70 \%$ & $0.92 \%$ & $0.92 \%$ & $0.95 \%$ & $1.03 \%$ & $1.15 \%$ & \\
\hline
\end{tabular}

Source: compiled by the author.

Return on equity (ROE) is another widely used profitability measure, where it measures the returns the bank makes to its shareholders. From table 3, it can be seen that WBK had the lowest ROE of only $0.97 \%$. AUB and NBK were the best performers where they were the only banks that achieved a ROE ratio that was more than $10 \%$.

Table 3. Banks ROE Comparison

\begin{tabular}{|c|c|c|c|c|c|c|c|c|c|c|}
\hline ROE & 2010 & 2011 & 2012 & 2013 & 2014 & 2015 & 2016 & 2017 & 2018 & Average \\
\hline ABK & $11.35 \%$ & $10.25 \%$ & $5.81 \%$ & $6.55 \%$ & $6.73 \%$ & $5.46 \%$ & $5.85 \%$ & $6.24 \%$ & $6.24 \%$ & $7.16 \%$ \\
\hline BBK & $2.87 \%$ & $10.18 \%$ & $10.12 \%$ & $5.17 \%$ & $7.61 \%$ & $10.51 \%$ & $7.89 \%$ & $7.96 \%$ & $8.83 \%$ & $7.91 \%$ \\
\hline CBK & $8.34 \%$ & $0.16 \%$ & $0.21 \%$ & $4.21 \%$ & $8.88 \%$ & $8.00 \%$ & $8.35 \%$ & $8.47 \%$ & $8.74 \%$ & $6.15 \%$ \\
\hline GBK & $4.64 \%$ & $7.12 \%$ & $6.88 \%$ & $6.66 \%$ & $6.93 \%$ & $7.25 \%$ & $7.49 \%$ & $7.99 \%$ & $9.03 \%$ & $7.11 \%$ \\
\hline NBK & $13.58 \%$ & $13.00 \%$ & $12.11 \%$ & $9.28 \%$ & $9.53 \%$ & $9.29 \%$ & $9.17 \%$ & $9.61 \%$ & $10.64 \%$ & $10.69 \%$ \\
\hline AUB & $8.66 \%$ & $9.25 \%$ & $12.86 \%$ & $13.28 \%$ & $13.68 \%$ & $9.68 \%$ & $8.45 \%$ & $10.15 \%$ & $10.43 \%$ & $10.72 \%$ \\
\hline BYK & $2.50 \%$ & $3.21 \%$ & $3.72 \%$ & $4.72 \%$ & $9.47 \%$ & $10.97 \%$ & $9.76 \%$ & $10.54 \%$ & $11.57 \%$ & $7.38 \%$ \\
\hline KFH & $4.57 \%$ & $2.53 \%$ & $7.82 \%$ & $7.63 \%$ & $7.63 \%$ & $8.17 \%$ & $9.00 \%$ & $10.12 \%$ & $12.67 \%$ & $7.79 \%$ \\
\hline KIB & $8.54 \%$ & $5.22 \%$ & $6.08 \%$ & $5.81 \%$ & $5.70 \%$ & $6.49 \%$ & $7.15 \%$ & $6.74 \%$ & $7.60 \%$ & $6.59 \%$ \\
\hline WBK & $\mathrm{n} / \mathrm{a}$ & $\mathrm{n} / \mathrm{a}$ & $-1.95 \%$ & $-4.09 \%$ & $0.13 \%$ & $1.08 \%$ & $2.72 \%$ & $4.21 \%$ & $4.70 \%$ & $0.97 \%$ \\
\hline Average & $7.23 \%$ & $6.77 \%$ & $6.37 \%$ & $5.92 \%$ & $7.63 \%$ & $7.69 \%$ & $7.58 \%$ & $8.20 \%$ & $9.04 \%$ & \\
\hline
\end{tabular}

Source: compiled by the author.

Liquid Assets to Total Assets ratio (L1) measures the ability of a bank to absorb liquidity shocks. A high ratio means a high ability to absorb shocks. From table 4, it can be seen that KFH was the most capable bank in absorbing any liquidity shocks where it achieved a ratio of $13.82 \%$ indicating that liquid assets presents $13.82 \%$ of its total assets. WBK was the most vulnerable bank in facing any unexpected liquidity shortfalls. 
Table 4. Banks L1 Comparison

\begin{tabular}{|c|c|c|c|c|c|c|c|c|c|c|}
\hline L1 & 2010 & 2011 & 2012 & 2013 & 2014 & 2015 & 2016 & 2017 & 2018 & Average \\
\hline ABK & $6.13 \%$ & $5.15 \%$ & $5.07 \%$ & $3.81 \%$ & $2.41 \%$ & $5.41 \%$ & $5.88 \%$ & $3.70 \%$ & $9.11 \%$ & $5.19 \%$ \\
\hline BBK & $17.85 \%$ & $12.45 \%$ & $13.16 \%$ & $14.03 \%$ & $13.42 \%$ & $12.88 \%$ & $10.57 \%$ & $10.85 \%$ & $13.39 \%$ & $13.18 \%$ \\
\hline CBK & $5.52 \%$ & $5.17 \%$ & $4.83 \%$ & $10.18 \%$ & $11.73 \%$ & $16.87 \%$ & $13.24 \%$ & $11.50 \%$ & $16.54 \%$ & $10.62 \%$ \\
\hline GBK & $4.48 \%$ & $5.32 \%$ & $3.73 \%$ & $6.86 \%$ & $7.66 \%$ & $10.86 \%$ & $8.17 \%$ & $8.06 \%$ & $8.85 \%$ & $7.11 \%$ \\
\hline NBK & $9.06 \%$ & $8.73 \%$ & $9.68 \%$ & $12.05 \%$ & $14.20 \%$ & $14.73 \%$ & $10.30 \%$ & $10.21 \%$ & $9.88 \%$ & $10.98 \%$ \\
\hline AUB & $15.62 \%$ & $16.11 \%$ & $10.15 \%$ & $12.07 \%$ & $2.47 \%$ & $8.82 \%$ & $1.20 \%$ & $1.15 \%$ & $1.97 \%$ & $7.73 \%$ \\
\hline BYK & $3.09 \%$ & $12.37 \%$ & $9.00 \%$ & $9.38 \%$ & $11.89 \%$ & $14.85 \%$ & $1.06 \%$ & $1.22 \%$ & $1.93 \%$ & $7.20 \%$ \\
\hline KFH & $14.04 \%$ & $14.14 \%$ & $11.42 \%$ & $7.48 \%$ & $14.98 \%$ & $19.31 \%$ & $16.77 \%$ & $12.09 \%$ & $14.15 \%$ & $13.82 \%$ \\
\hline KIB & $13.25 \%$ & $4.63 \%$ & $6.63 \%$ & $6.33 \%$ & $6.23 \%$ & $12.11 \%$ & $6.54 \%$ & $5.53 \%$ & $4.68 \%$ & $7.32 \%$ \\
\hline WBK & $\mathrm{n} / \mathrm{a}$ & $\mathrm{n} / \mathrm{a}$ & $2.61 \%$ & $4.47 \%$ & $1.03 \%$ & $0.50 \%$ & $0.49 \%$ & $0.74 \%$ & $0.90 \%$ & $1.53 \%$ \\
\hline Average & $9.89 \%$ & $9.34 \%$ & $7.63 \%$ & $8.67 \%$ & $8.60 \%$ & $11.63 \%$ & $7.42 \%$ & $6.51 \%$ & $8.14 \%$ & \\
\hline
\end{tabular}

Source: compiled by the author.

Liquid Assets to Deposits ratio (L2) is used to measure the bank liquidity in the case that the bank cannot borrow from other banks in order to repay its maturing or any pre-matured deposits. A high ratio means that the bank is able to cope with liquidity risk. BBK achieved the highest ratio in that category followed by NBK. Again WBK was the worst performer in that category, where the bank liquid assets represents only $2.10 \%$ of its total deposits.

Table 5. Banks L2 Comparison

\begin{tabular}{|c|c|c|c|c|c|c|c|c|c|c|}
\hline L2 & $\mathbf{2 0 1 0}$ & $\mathbf{2 0 1 1}$ & $\mathbf{2 0 1 2}$ & $\mathbf{2 0 1 3}$ & $\mathbf{2 0 1 4}$ & $\mathbf{2 0 1 5}$ & $\mathbf{2 0 1 6}$ & $\mathbf{2 0 1 7}$ & $\mathbf{2 0 1 8}$ & Average \\
\hline ABK & $8.94 \%$ & $7.54 \%$ & $8.20 \%$ & $6.24 \%$ & $4.35 \%$ & $9.45 \%$ & $8.68 \%$ & $5.23 \%$ & $12.69 \%$ & $\mathbf{7 . 9 3 \%}$ \\
\hline BBK & $27.70 \%$ & $19.51 \%$ & $19.07 \%$ & $20.63 \%$ & $21.08 \%$ & $21.48 \%$ & $18.40 \%$ & $17.97 \%$ & $23.17 \%$ & $\mathbf{2 1 . 0 0 \%}$ \\
\hline CBK & $8.80 \%$ & $8.52 \%$ & $7.85 \%$ & $15.21 \%$ & $19.35 \%$ & $26.76 \%$ & $24.24 \%$ & $22.54 \%$ & $31.46 \%$ & $\mathbf{1 8 . 3 0 \%}$ \\
\hline GBK & $6.53 \%$ & $7.46 \%$ & $5.43 \%$ & $10.18 \%$ & $11.02 \%$ & $15.39 \%$ & $12.79 \%$ & $12.77 \%$ & $13.88 \%$ & $\mathbf{1 0 . 6 0 \%}$ \\
\hline NBK & $18.29 \%$ & $17.50 \%$ & $16.73 \%$ & $20.91 \%$ & $25.92 \%$ & $27.07 \%$ & $18.98 \%$ & $18.19 \%$ & $18.50 \%$ & $\mathbf{2 0 . 2 3 \%}$ \\
\hline AUB & $17.85 \%$ & $18.31 \%$ & $11.63 \%$ & $13.68 \%$ & $2.77 \%$ & $9.87 \%$ & $1.38 \%$ & $1.35 \%$ & $2.30 \%$ & $\mathbf{8 . 7 9 \%}$ \\
\hline BYK & $3.83 \%$ & $14.98 \%$ & $10.57 \%$ & $10.86 \%$ & $13.63 \%$ & $16.73 \%$ & $1.22 \%$ & $1.40 \%$ & $2.19 \%$ & $\mathbf{8 . 3 8 \%}$ \\
\hline KFH & $17.87 \%$ & $17.79 \%$ & $14.42 \%$ & $9.10 \%$ & $17.96 \%$ & $23.15 \%$ & $20.45 \%$ & $14.62 \%$ & $16.80 \%$ & $\mathbf{1 6 . 9 1 \%}$ \\
\hline KIB & $16.36 \%$ & $5.82 \%$ & $8.23 \%$ & $7.65 \%$ & $7.48 \%$ & $14.44 \%$ & $7.83 \%$ & $6.63 \%$ & $5.53 \%$ & $\mathbf{8 . 8 8 \%}$ \\
\hline WBK & n/a & n/a & $4.67 \%$ & $5.81 \%$ & $1.22 \%$ & $0.57 \%$ & $0.53 \%$ & $0.84 \%$ & $1.05 \%$ & $\mathbf{2 . 1 0 \%}$ \\
\hline Average & $\mathbf{1 4 . 0 2} \%$ & $\mathbf{1 3 . 0 5 \%}$ & $\mathbf{1 0 . 6 8 \%}$ & $\mathbf{1 2 . 0 3 \%}$ & $\mathbf{1 2 . 4 8 \%}$ & $\mathbf{1 6 . 4 9 \%}$ & $\mathbf{1 1 . 4 5 \%}$ & $\mathbf{1 0 . 1 5 \%}$ & $\mathbf{1 2 . 7 6 \%}$ & \\
\hline
\end{tabular}

Source: compiled by the author.

L3 which is the ratio of total loans to total assets is set to measure illiquid assets compared to bank total assets. Having a high ratio would indicate that the bank is tying much of its assets in illiquid assets which would imply high bank illiquidity. On the other hand, low ratio would indicate low assets utilization from the bank which in turn would have a negative effect on the bank profitability. As seen in table 6, KFH had the lowest level indicating that $\mathrm{KFH}$ has $45.01 \%$ of its assets in the form of liquid assets, but again this low ratio does have an effect on the bank profitability as seen in table 2, where KFH was in the fifth place when it came to ROA. $\mathrm{ABK}$ had the highest level indicating that $\mathrm{ABK}$ uses $73.26 \%$ of its assets on loans which increases its liquidity risk in that category.

Table 6. Banks L3 Comparison

\begin{tabular}{|c|c|c|c|c|c|c|c|c|c|c|}
\hline L3 & 2010 & 2011 & 2012 & 2013 & 2014 & 2015 & 2016 & 2017 & 2018 & Average \\
\hline $\mathrm{ABK}$ & $71.63 \%$ & $71.06 \%$ & $71.81 \%$ & $73.04 \%$ & $73.60 \%$ & $74.77 \%$ & $76.10 \%$ & $75.61 \%$ & $71.72 \%$ & $73.26 \%$ \\
\hline BBK & $53.87 \%$ & $51.58 \%$ & $58.53 \%$ & $57.17 \%$ & $58.60 \%$ & $66.60 \%$ & $65.77 \%$ & $65.72 \%$ & $64.10 \%$ & $60.22 \%$ \\
\hline CBK & $72.12 \%$ & $62.03 \%$ & $60.88 \%$ & $62.05 \%$ & $58.76 \%$ & $60.84 \%$ & $59.01 \%$ & $55.69 \%$ & $55.91 \%$ & $60.81 \%$ \\
\hline GBK & $74.68 \%$ & $74.47 \%$ & $74.79 \%$ & $73.38 \%$ & $74.10 \%$ & $73.69 \%$ & $71.22 \%$ & $73.73 \%$ & $72.96 \%$ & $73.67 \%$ \\
\hline NBK & $63.05 \%$ & $62.39 \%$ & $62.75 \%$ & $59.84 \%$ & $57.03 \%$ & $60.02 \%$ & $58.91 \%$ & $58.07 \%$ & $56.29 \%$ & $59.82 \%$ \\
\hline AUB & $67.83 \%$ & $64.22 \%$ & $68.61 \%$ & $70.39 \%$ & $71.45 \%$ & $71.13 \%$ & $76.57 \%$ & $76.00 \%$ & $74.71 \%$ & $71.21 \%$ \\
\hline BYK & $64.48 \%$ & $68.62 \%$ & $69.06 \%$ & $69.08 \%$ & $69.68 \%$ & $70.89 \%$ & $73.88 \%$ & $73.92 \%$ & $76.66 \%$ & $70.70 \%$ \\
\hline $\mathrm{KFH}$ & $58.65 \%$ & $58.28 \%$ & $59.68 \%$ & $52.93 \%$ & $50.09 \%$ & $51.94 \%$ & $52.74 \%$ & $55.66 \%$ & $54.92 \%$ & $54.99 \%$ \\
\hline KIB & $67.02 \%$ & $64.39 \%$ & $65.22 \%$ & $67.45 \%$ & $66.99 \%$ & $67.90 \%$ & $71.40 \%$ & $70.43 \%$ & $76.40 \%$ & $68.58 \%$ \\
\hline WBK & $\mathrm{n} / \mathrm{a}$ & $\mathrm{n} / \mathrm{a}$ & $37.52 \%$ & $54.68 \%$ & $66.19 \%$ & $71.16 \%$ & $74.59 \%$ & $72.34 \%$ & $74.64 \%$ & $64.44 \%$ \\
\hline Average & $65.93 \%$ & $64.12 \%$ & $62.89 \%$ & $64.00 \%$ & $64.65 \%$ & $66.89 \%$ & $68.02 \%$ & $67.72 \%$ & $67.83 \%$ & \\
\hline
\end{tabular}

Source: compiled by the author.

Loans to deposits ratio (L4) indicates the relationship of illiquid assets and liquid liabilities. When this ratio is high, it means that the bank is less liquid. ABK showed the highest ratio, as seen in table 7, which indicates 
that the bank is using $114.11 \%$ of its customers' deposits in loans granting. On the other side, KFH only uses $67.42 \%$ of its deposits in loans.

Table 7. Banks L4 Comparison

\begin{tabular}{|c|c|c|c|c|c|c|c|c|c|c|}
\hline $\mathbf{L 4}$ & 2010 & 2011 & 2012 & 2013 & 2014 & 2015 & 2016 & 2017 & 2018 & Average \\
\hline ABK & $104.47 \%$ & $104.09 \%$ & $116.11 \%$ & $119.77 \%$ & $132.87 \%$ & $130.57 \%$ & $112.44 \%$ & $106.76 \%$ & $99.91 \%$ & $114.11 \%$ \\
\hline BBK & $83.61 \%$ & $80.86 \%$ & $84.78 \%$ & $84.03 \%$ & $92.04 \%$ & $111.06 \%$ & $114.51 \%$ & $108.86 \%$ & $110.97 \%$ & $96.75 \%$ \\
\hline CBK & $114.96 \%$ & $102.22 \%$ & $98.93 \%$ & $92.69 \%$ & $96.92 \%$ & $96.47 \%$ & $108.08 \%$ & $109.16 \%$ & $106.31 \%$ & $102.86 \%$ \\
\hline GBK & $108.88 \%$ & $104.40 \%$ & $108.79 \%$ & $108.96 \%$ & $106.60 \%$ & $104.43 \%$ & $111.39 \%$ & $116.72 \%$ & $114.46 \%$ & $109.40 \%$ \\
\hline NBK & $127.36 \%$ & $125.05 \%$ & $108.40 \%$ & $103.84 \%$ & $104.09 \%$ & $110.32 \%$ & $108.60 \%$ & $103.43 \%$ & $105.43 \%$ & $110.72 \%$ \\
\hline AUB & $77.53 \%$ & $72.99 \%$ & $78.65 \%$ & $79.75 \%$ & $80.05 \%$ & $79.56 \%$ & $88.51 \%$ & $88.86 \%$ & $87.46 \%$ & $81.48 \%$ \\
\hline BYK & $79.93 \%$ & $83.10 \%$ & $81.14 \%$ & $79.97 \%$ & $79.89 \%$ & $79.84 \%$ & $85.14 \%$ & $84.40 \%$ & $87.24 \%$ & $82.29 \%$ \\
\hline KFH & $74.64 \%$ & $73.31 \%$ & $75.34 \%$ & $64.36 \%$ & $60.04 \%$ & $62.25 \%$ & $64.30 \%$ & $67.30 \%$ & $65.20 \%$ & $67.42 \%$ \\
\hline KIB & $82.72 \%$ & $81.04 \%$ & $80.95 \%$ & $81.49 \%$ & $80.46 \%$ & $80.92 \%$ & $85.42 \%$ & $84.47 \%$ & $90.24 \%$ & $83.08 \%$ \\
\hline WBK & $\mathrm{n} / \mathrm{a}$ & $\mathrm{n} / \mathrm{a}$ & $67.22 \%$ & $71.07 \%$ & $78.86 \%$ & $81.48 \%$ & $82.04 \%$ & $81.27 \%$ & $86.69 \%$ & $78.38 \%$ \\
\hline Average & $94.90 \%$ & $91.89 \%$ & $90.03 \%$ & $88.59 \%$ & $91.18 \%$ & $93.69 \%$ & $96.04 \%$ & $95.12 \%$ & $95.39 \%$ & \\
\hline
\end{tabular}

Source: Compiled by the author.

L5 is the ratio of financing gap to total assets, it is used to measures liquidity risk exposure. The ratio is defined as the difference between a bank's loans and customer deposits divided by total assets. Having a higher ratio would imply higher profitability and lower liquidity. ABK showed the highest ratio, as seen in table 8 , while KFH had the lowest ratio.

Table 8. Banks L5 Comparison

\begin{tabular}{|l|c|c|c|c|c|c|c|c|c|c|}
\hline L5 & $\mathbf{2 0 1 0}$ & $\mathbf{2 0 1 1}$ & $\mathbf{2 0 1 2}$ & $\mathbf{2 0 1 3}$ & $\mathbf{2 0 1 4}$ & $\mathbf{2 0 1 5}$ & $\mathbf{2 0 1 6}$ & $\mathbf{2 0 1 7}$ & $\mathbf{2 0 1 8}$ & Average \\
\hline ABK & $3.07 \%$ & $2.79 \%$ & $9.96 \%$ & $12.06 \%$ & $18.21 \%$ & $17.51 \%$ & $8.42 \%$ & $4.79 \%$ & $-0.06 \%$ & $\mathbf{8 . 5 3 \%}$ \\
\hline BBK & $-10.56 \%$ & $-12.21 \%$ & $-10.51 \%$ & $-10.86 \%$ & $-5.07 \%$ & $6.63 \%$ & $8.33 \%$ & $5.35 \%$ & $6.34 \%$ & $\mathbf{- 2 . 5 1 \%}$ \\
\hline CBK & $9.38 \%$ & $1.35 \%$ & $-0.66 \%$ & $-4.89 \%$ & $-1.87 \%$ & $-2.23 \%$ & $4.41 \%$ & $4.67 \%$ & $3.32 \%$ & $\mathbf{1 . 5 0 \%}$ \\
\hline GBK & $6.09 \%$ & $3.14 \%$ & $6.04 \%$ & $6.03 \%$ & $4.59 \%$ & $3.12 \%$ & $7.28 \%$ & $10.56 \%$ & $9.22 \%$ & $\mathbf{6 . 2 3} \%$ \\
\hline NBK & $13.55 \%$ & $12.50 \%$ & $4.86 \%$ & $2.21 \%$ & $2.24 \%$ & $5.61 \%$ & $4.67 \%$ & $1.93 \%$ & $2.90 \%$ & $\mathbf{5 . 6 1 \%}$ \\
\hline AUB & $-19.65 \%$ & $-23.77 \%$ & $-18.62 \%$ & $-17.87 \%$ & $-17.81 \%$ & $-18.27 \%$ & $-9.94 \%$ & $-9.53 \%$ & $-10.71 \%$ & $\mathbf{- 1 6 . 2 4 \%}$ \\
\hline BYK & $-16.19 \%$ & $-13.95 \%$ & $-16.05 \%$ & $-17.30 \%$ & $-17.54 \%$ & $-17.90 \%$ & $-12.90 \%$ & $-13.66 \%$ & $-11.22 \%$ & $\mathbf{- 1 5 . 1 9 \%}$ \\
\hline KFH & $-19.93 \%$ & $-21.22 \%$ & $-19.53 \%$ & $-29.31 \%$ & $-33.33 \%$ & $-31.49 \%$ & $-29.29 \%$ & $-27.04 \%$ & $-29.31 \%$ & $\mathbf{- 2 6 . 7 2 \%}$ \\
\hline KIB & $-14.00 \%$ & $-15.07 \%$ & $-15.35 \%$ & $-15.32 \%$ & $-16.27 \%$ & $-16.01 \%$ & $-12.18 \%$ & $-12.95 \%$ & $-8.26 \%$ & $\mathbf{- 1 3 . 9 3 \%}$ \\
\hline WBK & $\mathrm{n} / \mathrm{a}$ & $\mathrm{n} / \mathrm{a}$ & $-18.30 \%$ & $-22.25 \%$ & $-17.74 \%$ & $-16.18 \%$ & $-16.33 \%$ & $-16.67 \%$ & $-11.46 \%$ & $\mathbf{- 1 6 . 9 9 \%}$ \\
\hline Average & $\mathbf{- 5 . 3 6 \%}$ & $\mathbf{- 7 . 3 8 \%}$ & $\mathbf{- 7 . 8 2 \%}$ & $\mathbf{- 9 . 7 5 \%}$ & $\mathbf{- 8 . 4 6 \%}$ & $\mathbf{- 6 . 9 2 \%}$ & $\mathbf{- 4 . 7 5 \%}$ & $\mathbf{- 5 . 2 6 \%}$ & $\mathbf{- 4 . 9 3 \%}$ & \\
\hline
\end{tabular}

Source: Compiled by the author.

Descriptive analysis is presented in table 9, where it can be seen that the average ROA for the banks under study during the study period was $0.90 \%$ and the mean ROE was $0.74 \%$. When it comes to liquidity variables it can also be seen that the mean L1 ratio was $8.60 \%$ and $12.5 \%$ for L2. While loans to total assets (L3) ratio was $65.8 \%$ meaning that, on an average, Kuwaiti banks uses $65.8 \%$ of their total assets in customers loans. When it comes to loans to deposits ratio (L4) it can be seen that the banks utilize $93.0 \%$ of their customers deposits in loans granting. Using kurtosis and skewness results to identify distribution normality of the data, it can be seen that both of then fall within the acceptable range of normal distribution since the data fall between \pm 2 and \pm 10 for skewness and kurtosis respectively.

Table 9. Descriptive analysis

\begin{tabular}{|c|c|c|c|c|c|c|c|}
\hline & $R O A$ & $R O E$ & $L 1$ & $L 2$ & $L 3$ & $L 4$ & $L 5$ \\
\hline Mean & 0.009 & 0.074 & 0.086 & 0.125 & 0.658 & 0.930 & -0.067 \\
\hline Median & 0.010 & 0.079 & 0.089 & 0.127 & 0.672 & 0.880 & -0.102 \\
\hline Standard Deviation & 0.005 & 0.034 & 0.049 & 0.075 & 0.080 & 0.172 & 0.126 \\
\hline Kurtosis & 2.976 & 1.044 & -0.996 & -0.744 & 0.243 & -0.794 & -1.036 \\
\hline Skewness & -0.717 & -0.773 & 0.033 & 0.215 & -0.717 & 0.220 & -0.033 \\
\hline Count & 88 & 88 & 88 & 88 & 88 & 88 & 88 \\
\hline
\end{tabular}

Source: Compiled by the author.

Pearson correlation matrix is used to identify the strength and the direction of the relation between the variables. The matrix is also used to detect multicollinearity which can cause unrealistically high standard error estimates of regression coefficients and in the end can cause false conclusion about the significance of independent variables in the model being evaluated. The threshold used to examine multicollinearity between the variables is 0.70 . From table 10 , it can be seen that there is no multicollinearity between the variables. 
Table 10. Pearson Correlation Matrix

\begin{tabular}{|c|c|c|c|c|c|c|c|}
\hline & $R O A$ & $R O E$ & $L 1$ & $L 2$ & $L 3$ & $L 4$ & $L 5$ \\
\hline ROA & 1 & & & & & & \\
\hline ROE & 0.918 & 1 & & & & & \\
\hline L1 & 0.262 & 0.281 & 1 & & & & \\
\hline L2 & 0.331 & 0.298 & 0.534 & 1 & & & \\
\hline L4 & 0.091 & 0.117 & -0.572 & -0.598 & 1 & & \\
\hline L5 & 0.309 & 0.182 & -0.149 & 0.116 & 0.352 & 1 & \\
\hline
\end{tabular}

Source: Compiled by the author.

The panel OLS regression results are presented in table 11, where it can be seen from model 1 that liquidity ratios used were able to explain $35.8 \%$ of variation in ROA which can be categorized as low effect since adjusted R square was less than 0.5. But nevertheless the model can be labeled as a "good fit" since $F$ sig was less than 0.05 . Model 1 results shows a statistically significant inverse relation between return on assets (ROA) and both L1 and L2, while there was statistically significant direct relation with L3, L4, and L5.

In terms of model 2 , it can be seen that the model had a low explanatory power of only $27.8 \%$ of the variation in ROE but still had a sig $F$ that is less than 0.05 indicating a good fit model. Results from model 2 shows a statistically significant inverse relation between L2 and return on equity (ROE), while there was a statistically significant direct relation with L3, L4, and L5. The results also show that liquid assets to total assets ratio (L1) does not have any significant effect on return on equity (ROE).

Table 11. Panel OLS Regression Results

\begin{tabular}{|c|c|c|c|c|c|c|c|}
\hline \multicolumn{4}{|c|}{ Model 1 (ROA) } & \multicolumn{4}{|c|}{ Model 2 (ROE) } \\
\hline Adj R Square & 0.358 & & & Adj R Square & 0.278 & & \\
\hline Standard Error & 0.004 & & & Standard Error & 0.029 & & \\
\hline Significance F & 0.000 & & & Significance F & 0.000 & & \\
\hline Observations & 88 & & & Observations & 88 & & \\
\hline & Coefficients & $t$ Stat & P-value & & Coefficients & $t$ Stat & $P$-value \\
\hline Intercept & $-0.097 * * *$ & -4.937 & 0.000 & Intercept & $-0.534 * * *$ & -3.817 & 0.000 \\
\hline L1 & $-0.078^{*}$ & -1.687 & 0.095 & L1 & -0.380 & -1.153 & 0.252 \\
\hline L2 & $-0.087 * *$ & -2.593 & 0.011 & $\mathrm{~L} 2$ & $-0.520 * *$ & -2.170 & 0.033 \\
\hline L3 & $0.024 * *$ & 2.416 & 0.018 & L3 & $0.212 * * *$ & 2.987 & 0.004 \\
\hline L4 & $0.084 * * *$ & 4.214 & 0.000 & $\mathrm{~L} 4$ & $0.423 * * *$ & 2.973 & 0.004 \\
\hline L5 & $0.119 * * *$ & 4.379 & 0.000 & L5 & $0.636 * * *$ & 3.291 & 0.001 \\
\hline
\end{tabular}

$*, * *, * * *$ represents confidence level at $90 \%, 95 \%$, and $99 \%$ respectively.

Source: Compiled by the author.

\section{Conclusion}

This study was set to examine the effect of liquidity on the financial performance of ten Kuwaiti banks over the period 2010-2018. Examining the effect of five liquidity ratios on the financial performance of the banks, using return on assets (ROA) and return on equity (ROE) as financial performance proxies, revealed that all five liquidity ratios used in this study had a significant effect on return on assets (ROA) while only four of them had a significant effect on return on equity (ROE). These relations varied from direct to inverse relations which explains the mixed results shown in literature in that matter, since the direction of the effect of liquidity on the financial performance depends on the ratio used. The results also showed that liquidity ratios explain $35.8 \%$ and $27.8 \%$ of the variations in both return on assets (ROA) and return on equity (ROE) respectively. This would indicate the importance of managing the liquidity in Kuwaiti banks and that bank management should emphasize on the bank liquidity due to its importance to both the investors and the depositors of the bank.

\section{References}

1. Al-Yatama, S. K., AlAli, M. S., Al Awadhi, K. M., and Al Shamali, N. M. (2020). The Effect of Credit Risk, Operational Risk and Liquidity Risk on the Financial Performance of Insurance Companies Listed at Kuwait Stock Exchange, European Journal of Economic and Financial Research, 3(6), 1-8. https://doi.org/10.5281/zenodo.3605378

2. Amengor, C. (2010). Importance of Liquidity and Capital Adequacy to Commercial Banks, A Paper Presented at Induction Ceremony of ACCE, UCC Campus. 
3. Bourke, P. (1989). Concentration and Other Determinants of Bank Profitability in Europe, North America and Australia, Journal of Banking and Finance, 13, 65-79. https://doi.org/10.1016/0378-4266(89)90020$\underline{4}$

4. Eichengreen, B. and H.D. Gibson (2001). Greek banking at the dawn of the new millennium. CERP Discussion Paper 2791, London. Available at: https://repec.cepr.org/repec/cpr/ceprdp/Dp2791.pdf

5. Goddard, J., Molyneux, P. and Wilson, J.O.S. (2004). Dynamics of Growth and Profitability in Banking, Journal of Money, Credit and Banking, 36, 1069-1090. Available at: http://citeseerx.ist.psu.edu/viewdoc/download?doi=10.1.1.203.1972\&rep=rep1\&type=pdf

6. Heibati F, Nourani S, and Dadkhah S. (2009). Evaluation of the Performance of Private banks of Iran in Comparison to the banks of Arabic countries, Persian Gulf area, Economic Research Letter, 6(1), 28-32. Available at: https://www.sid.ir/en/Journal/ViewPaper.aspx?ID=201412

7. Idowu A, Essien, J, Adegboyega R. (2017). Iquidity management and banks performance in Nigeria, Business Management and Economics, 5(6), 88- 98. https://doi.org/10.15739/IBME.17.010

8. Imad Ramadan Z, Qais Kilani A, Thair Kaddumi A. (2011). Determinants of Bank Profitability: Evidence from Jordan, International Journal of Academic Research, 3(4), 180-191. Available at: https://www.asu.edu.jo/ar/Economics/thair_lion/Documents/14.pdf

9. Kehinde, O. P. (2013). An Empirical Investigation of the Liquidity-Profitability Relationship in Nigerian Commercial Banks, Journal of Economics and Sustainable Development, 4 (6), 118-119. Available at: https://www.iiste.org/Journals/index.php/JEDS/article/view/5220

10. Molyneux, P. and Thornton, J. (1992). Determinants of European Bank Profitability: A Note, Journal of Banking and Finance, 16, 1173-1178. Available at: https://eclass.hmu.gr/modules/document/file.php/DA171/Assignment\%20Examples/Banks\%20Profitabil ity/Molyneux Thornton_1992.pdf

11. Nzzotta SM (1997). Money, Banking and Finance: Theory and Practice. Owerri: Abuchi Press

12. Olagunju, A., Adeyanju, O. D. and Olabode, O. S. (2011). Liquidity Management and Commercial Banks' Profitability in Nigeria, Research Journal of Finance and Accounting, 2(7/8), 24-38. Available at: https://iiste.org/Journals/index.php/RJFA/article/view/1283/1204

13. Osborn, M., Fuertes, A. and Milne, A. (2012). Capital and Profitability in Banking: Evidence from US Banks, Business journal, 4(9), 203-214. Available at: http://www.cass.city.ac.uk/_data/assets/pdf_file/0013/152122/Osborne_Matthew_Capital-and-earningsin-banking-Emerging-Scholars.pdf 